and country had no such opportunities for preparation. Considering then the danger to themselves should the Armenians become masters of the Caucasus the Tartars had every incentive to taken forceful steps to counter the Armenian preparations.

But to just what extent the Tartars unaided from without could have met this situation it is difficult to say. From where were they to obtain arms, and from where the means of purchasing the things they required? While also the question of leadership was no mean factor. In Tiflis British and French officers were behind the whole of the Armenian movement. There was British and American money in abundance sent out to them for their needs. Behind the Tartars were the agents from Turkey and Germany, and to welcome these and even send for them would have been the natural outcome of the situation for the Tartars.

Events soon proved the presence of these foreign agents behind the Tartars. Not only were there spread manifestoes calling upon the Tartars to look to Turkey as their natural home and ally, but it became plain that there was an active programme of organised action in the different places of the Caucasus to prove the existence of a real external leadership. The first consideration for the Tartars was arms. At the time, every piece of railway line from the Turkish front and the Persian front through Tiflis to Russia was blocked with the enormous traffic of returning Russian troops. With these troops were masses of military stores from field guns down to rifles and wagons. Here then was a source of supply for the little-armed Tartars. As shown above, all these railway lines passed through Tartar territory. There thus soon began a very carefully planned system of obstruction along all those portions of the railway toward Russia. The trains were held up and fired on. As time went on and some success began to be registered, more and more equipment falling into the hands of the Tartars, the obstructions grew more serious, till finally they became actually permanent, and the trains through just those more centralised Tartar districts were com- 
pelled to cease running. The Tartars had taken control.

This obstruction, it will be seen, was more than a mere method of gaining supplies from the retreating Russians when success had been fully registered. It meant as well the blocking of all communication between the Armenians at the Tiflis centre with the fronts, and the congesting within the Caucasian towns of thousands of Bolsheviki Russian soldiers who had no sympathy whatsoever with the Armenian national morements. Following the railway displacement came the cutting of wires so that in the months of February and March, 1918, the Caucasus became actually cut off from communication with the outside world.

There were thus given to the Armenians two things to accomplish. Firstly they must root out the Tartar control over the lines, and secondly they must rid themselves of the Russians. There at the fronts were the huge stores they needed for any campaign against the Turks, and so far as the situation had grown these stores were falling to the Turks without themselves having power to get within reach of them. There thus began local war between the Tartars and Armenians. What was to have been a Caucasian campaign against the Turks, had when March was reached become a localised internal war against Tartar villages and small Armenian communities. But the Tartars began this war. It was they who first endeavoured to clear out from their midst the Armenian village populations which were gradually receiving arms from the central government. This warfare was prosecuted with great vigour and barbarity. Whole villages of either Armenians or Tartars, as the case was would be sacked and burnt, till the plains of the Southern and Northern Caucasus became marked daily with clouds of ascending smoke, and fleeing refugees. It is to be noted that the Georgians in this work sided and assisted the Tartars.

The final outcome of this condition was the natural linking up of this Tartar movement with a similar rise of the same Mohammedan elements in northern and western Persia. In this the wider scheme and wider control 
more emphatically showed itself. This new Persian factor began at the moment when the localised Caucasian warfare was in full force. The new movement arose very suddenly, and very completly. Within a few days, it seemed, like a gust of wind, the whole Azerbaijanis peoples from Enzelli on the Caspian to Tabriz and to the Khurdistan hills rose and threw over the old control of the Persian Shah. Deputies came through the Tartarheld line from Persia to Erivan, the last Armenian outpost; while at Baku on the north the Tartars became restive under the installed Russian Bolshiviki rule which had resulted, from a very great congestion of fleeing Russians in the one town. A great fight took place here in the middle of March in which however the Tartars were for the time being badly beaten, but with the fall of Batum to the Turks, and the capture of Kars and then Alexandropol by another force of the Turks, there is no doubt at all that Baku was doomed to become the possession of the Tartars in a second struggle. The opening of the Volga gave the needed outlet back to Russia for the Bolsheviki, and the dwindling of their numbers must inevitably leave the few remnants and the local Armenians a prey to the naturally large population of Mohammedans. It was the result of the Tiflis Armenians endeavours to rid the Caucasus, especially the central Armenian portions, of the Russian Bolsheviki which had caused Baku to become for the time their chief rallying point.

If the above has been a sufficient summary of the general conditiuns in the Caucasus during the period of the war it should be possible to consider that the movements which finally developed as a Mohammedan plan of action against the Christians came about from two opposite causes. Firstly there was the pressure from without composed of propaganda on political lines to encourage a linking up of the national ideals of the Caucasian Tartars with the national ideals of the Osmanli Turks; while secondly there grew up an internal condition resulting from the Armenian war preparations which compelled the Tartars to look to themselves and Turkish 
help for their own preservation. I think, that to those of us who were very closely bound up with all that was going on through these different periods, and were closely associated with both Tartar and Armenian, it is safe to say that the mere pressure from without would have had but small effect upon the mass of the Mohammedan peoples. The Caucasian Mohammedans are unlike those of Turkey in many ways. There was a quietness and contentment about them, and an orderly relation between them and the Armenians of the Caucasus, which did not encourage in them a spirit of revolt unless their own existing status should become endangered. It is of course very difficult to fathom the unfathomable Mohammedan. But this estimate of the Caucasian Tartar was what those of us who lived amongst them felt to be the most nearly correct, and certainly the course of events did not contradict our beliefs. Eventually the Tartar, without doubt, was compelled into rising and siding as he did. From his point of view the Armenian national movement to arm was a direct menace to his own peace and existence. Moreover the progress of the Turks and the rise of the Azerbaijanis in Persia brought him indefinitely into the very midst of a Pan-Tartar movement which inevitably must carry him along. But undoubtedly the Tartar of the Caucasus had never a close affinity with the Osmanli Turk, and given other conditions would hardly have chosen events to have worked out exactly in this way. The larger movement from Turkey finally enveloped him.

Thomas B. Heald. 


\section{MOHAMMEDANS AND THE UNSEEN "PRESENCE"}

THERE WAS held in the city of New York, January 14, 1913, a Conference upon Missionary Work for Mohammedans which was attended by several score of Missionaries, Missionary Secretaries, and others interested. Many phases of work among Moslems were presented. As part of the discussion on Methods of Work, I ventured to make the following remarks which I now quote from the published Proceedings of the Conference (Foreign Missions Library, i 56 Fifth Avenue, New York).

"The Rev. Harvey Reeves Calkins, of India: May I add one word, not to discuss it, but to bring it to your attention. It is, it seems to me, a vital point, and has as yet received but scant consideration. I refer to the repetition of pentecostal conditions, now capable of illustration in the Punjab and the United Provinces, and, latterly, in parts of South India. Here a great, increasing, and spiritual Church is brought closely in contact with Mohammedan neighborhoods or Mohammedan constituencies. There may be no direct effort to reach Mohammedans as such. Indeed the 'indirect' approach is immediately and spiritually 'direct', for the Mohammedan, by the very nature of his own inwrought faith, is marvelously open to the influence of the Holy Spirit. When, under revival conditions, he recognizes the working of an unseen power, the appeal is to him practically irresistible. There is, I think, a reason for this. He is not mentally engaged in combating a direct presentation of Christian 'teaching', and is therefore not 'on guard.' He is conscious of a supernatural, and, to him, inexplicable Presence. The very habit of his mind will compel him to say, 'It is Kismet-fate,' and he will yield an amazed yet absolute obedience. I am convinced that here is an open door of approach to Mohammedan communities that has not yet received its full consideration in current discussions of the impact of Christianity upon Islam."

During my furlough in America, now extended for six years in serving the Stewardship Movement of the Churches, I have read eagerly every accessible report of missionary work among Mohammedans, and have sought to keep in touch with advance movements. That I have seen no discussion of this particular subject was due, it seemed to me, to the inevitable crowding of my present 
task, and to my own failure to keep in touch with late developments in mission lands.

Recently I was in conversation with Dr. Samuel $M$. Zwemer, just returned to America, and greedily received late news from the Mohammedan front as a hungry soldier receives an unexpected ration. I learned that what I have ventured to call the "indirect approach" to the Mohammedan mind has not been discussed to any degree, if at all, in missionary literature. "It is a new emphasis," he said. At Dr. Zwemer's request I am making some extension and illustration of my remarks at the New York Missionary Conference, though I do so with a degree of diffidence. A missionary in the reserves may not speak with such boldness as one in the trenches.

First of all, a sordid historic background gives the pentecostal approach to Mohammedans a peculiar significance. The Arabian prophet's ignorant reference to our Lord's promise of the Comforter is a singular inversion of the spiritual appeal. "Jesus the Son of Mary said, O children of Israel, verily I am the apostle of God sent unto you, confirming the law which was delivered before me, and bringing good tidings of an apostle who shall come after me, and whose name shall be Ahmed." (Sura LXI by Sale.) Students of Islam will recall that the Mohammedan doctors not only unanimously interpret these words of the Koran as referring to the Paracletos, but, by a cunning change of the Greek substantive to Periclytos (the illustrious one), actually turn it into a loose translation of the name Ahmed itself, one of Mohammed's appellations.

I remember with what amazement I first learned of this blasphemous interpretation of the most precious Christian doctrine of the Holy Spirit. It was when I was reading Gibbon's Decline and Fall of the Roman Empire and found in the fiftieth chapter what I still consider to be one of the most satisfactory presentations of the rise of Islam-for the sufficient reason that the Arabian movement is there kept related to a complex contemporary history. The monstrous claim of Mohammed that he himself was "the other Comforter" seemed 
to me, even then, to be high spiritual challenge to the missionaries of Jesus Christ.

I think this must have been in the background of my thought during my first year in India. I was pastor of the Grant Road English Church, Bombay, when a deep revival spirit became manifest among the members. With the co-operation of some of the Bombay laymen we began outdoor meetings and, almost immediately, found ourselves at the center of a unique movement which developed into the present Bombay Hindustani Church. Hindus, Parsis, and Mohammedans came from the street meetings-athough the indoor services were entirely in English-and there were a number of conversions and baptisms from these communities. Among them were several intelligent Mohammedans. Their simplicity in confessing Christ, and the constancy of their testimony, I have never forgotten. The whole movement was so spontaneous and natural that I did not learn until afterwards that some of the older missionaries considered it "unusual."

The "indirect" method of approach is illustrated by the story of Ilahi Baksh whose conversion is typical of what I am seeking to say. He was of a good Mohammedan family in the Punjab and had come to Bombay as a young merchant. One day he was passing the Dharamsala near Grant Road when he stopped to listen to a Christian giving testimony at a street meeting. After the street meeting the Christian people entered the Church and continued in prayer and song and testimony while Ilahi Baksh sat near the door and listened. He could not understand all that was spoken but the testimony of 2 young Christian girl reached him and filled him with strange forebodings-the girl's simple statement that she had been in great perplexity and distress, that she had prayed to God and He had answered her and given her the desire of her heart. Nothing could have been nearer the unchanging base of experimental Christianity: a soul in need, a prayer, God's answer. Ilahi Baksh was seized with consternation and went back to his shop in sullen rage. (He used so often to tell me the story of his con- 
version that it seems to have become a vivid experience of my own, although, as a matter of fact, it had occurred several years before, during a similar revival at Grant Road Church under the ministry of Rev. W. W. Bruere.)

"All these years," he said to himself, "I have prayed five times every day, yet God never has given me an answer; and here a Christian girl prays and the answer comes at once. I'll show these Christians that God will listen to a Mohammedan as quickly as to them, and give an answer tool"

Not a seemly approach, surely, to the High and Holy Onel Yet God, Who is a Spirit, was present in a Bombay chawl that day, and Ilahi Baksh found Him.

"I shut the doors of my shop," he told me, "and for the first time in my life threw away my Arabic formulas and prayed out of my heart; as I prayed it was as though a Voice spoke to me, 'You are praying like a Christian and you are one,' and I fell on the ground and melted like wax." The next morning before breakfast he was at the Mission House asking for baptism. Ilahi Baksh found Christians friends who enabled him to secure an education in America. He returned to India during my Grant Road pastorate and became the leader of our Bombay Hindustani work. Afterwards he was transferred to Ballia, in North India, where he became a notable Christian preacher and evangelist. Cholera overtook him in the midst of tender ministries among the sick and dying.

I have memoranda of other Bombay conversions among Mohammedans, not so striking as that of Ilahi Baksh, but illustrating no less perfectly what has seemed to me a peculiarly open avenue of approach in reaching them. I learned then, what missionaries to Moslems fully recognized, that there is a strain of mysticism in the Mohammedan mind in spite of his material and often sensual interpretation of spritual truth. As for devout and high minded Mohammedans, they nearly always are mystics. After three years in Bombay we were stationed at Cawnpore in the Northwest Provinces. For a number of years the work of village and city schools, the development of industrial shops, and the problems connected with 
the administration of an important district consumed my whole thought. It was not until our sixth year in Cawnpore, the year before our furlough, that we found ourselves in the midst of revival conditions that again made possible observation and experience of the direct working of the Spirit of God among Mohammedans. We of course had dealt with Mohammedans in our school work and village preaching, but I now am writing of the "pentecostal" approach that grows out of a true Christian revival.

In March, 1909, a remarkable spiritual movement swept through the Christian community of Cawnpore and continued for three months with increasing power. The outstanding mark of it was prayer. The Church itself was girded with strength and lifted to a place of Chtistian leadership. Twice daily for ten weeks our great central church in the heart of the native city was packed with people. The meetings were spontaneous and free, with special emphasis on prayer and the preaching of the Word. Much time was given to song, praise, and testimony. During all those strenuous weeks I made extensive daily notes, which I have preserved, and from which I now gather a few excerpts bearing on the present discussion.

The following entry describes a common occurrence: "I talked quietly on Matt. 10:28 and called for seekers. We were singing Isa Kaisa Dost Piyara when I saw a young Mohammedan trying to get his hand above his head. I smiled encouragement and he immediately stood up and walked to the front. I motioned to Ishwari Pershad who took him by the arm and they kneeled at the altar in prayer while I continued the invitation. I then called the altar service which continued with considerable power while I talked and prayed with the seekers. When I reached the Mohammedan he prayed after me, but not with great spirit. When I said, 'Lord Jesus, I am now ready to be baptized in thy name,' he halted. I looked up and he said, 'Tomorrow I will be ready.' I then prayed that God would deepen conviction and left him while Thomas John continued to pray and 
talk with him. He said he had not had rest for ten days and could not keep away from the meetings. Inayat Masih (a Mohammedan convert whom I had baptized several days before) sat back with Daftari. After the service he was talking, full of life and spirit, and said he wanted to learn Zor hai Zor. Misri Lal got in front of him and Thomas at his left ear; they loaded him with melody while I lay back and laughed. Mrs. - and Miss - remained in the gallery to pray with three purdah women who had been sitting through the entire service."

The following was somewhat unusual: "About 8:15 the church was packed by a large crowd of Mohammedans who came in a body headed by four moulvies. Presently a pert looking fellow walked up the aisle and interrupted Mrs. - who was reading in Isaiah. She bowed to him politely and said, 'Speak, please, after I have finished,' and Gulzari hustled him into a seat like a bag of bajral Then Mati Izhaq and Gulzari walked the main aisle like policemen, it was well done. Presently Benjamin came up and whispered to me that a disturbance was brewing as soon as the Bible reading was finished. I told his not to be disturbed, to sit perfectly quiet, and believe God. At the close of the reading I called on Bella John to pray. While she bowed inside the altar many Mohammedans stood up, looked around, and then sat down again. Bella went on praying with increasing power when suddenly, as though one man, fully 125 or I 50 men sprang to their feet and made for the doors. They ran as though they had been seized by panic. They could not get through the doorways quickly enough and stuck in the aisles. Bella finished and I started the Lord's prayer, the Christians joining. We repeated the prayer three times while the crowd got through the doors. It was an utter rout. As soon as they were all out we started a testimony meeting and the crowd began to fill in again, by twos and threes. They looked foolish as though they could not understand why they had left in the first place. We had victorious Christian testimonies for about fifteen minutes and then quietly dismissed." 
The case of Inayat Masih (his baptismal name, and the only one I seem to have entered in my notes), to whom reference already has been made, is not without human interest. His conversion caused no comment until it had been heralded in the city. The following excerpts cover about one month and begin shortly after his baptism.

"Inayat Masih came to me at the altar service and wanted to know how to pray. Masih Charan who knelt by him helped me greatly by telling him that he must pray like a little boy asking something from his father. Inayat then wanted to know if he should close his eyes or keep them open, and if he should sit or kneel. I told him to kneel like the rest of us, and to open or shut his eyes, just as he felt like doing, and to pray out of his heart for the things that he wanted, telling him of a dozen things that he might pray for. He threw back his head, opened his eyes wide, spread his hands in front of him, and began in a strong clear voice. He prayed with considerable understanding for 'sinners', for Mohammedans, for the whole city, and then for Mrs. - We all said 'Amen!' Then, as I was dismissing the service with prayer, he began again, taking the words out of my mouth and repeating them. I smiled at him and told him to listen until I had finished. When he had become quiet I went ahead and he kneeled in front of me puncturing every sentence of mine with 'Aminl' $\mathrm{He}$ is catching on and will learn very fast. . . Tonight I was disturbed to see Inayat Masih sitting back. A number of evil looking Mohammedans were sitting near him. After most of the crowd had gone I spoke to him to come forward, but he would not. I prayed, and when I looked up, the Church had again filled with people. Again I called Inayat to come and join us at the altar service and he came. I am disturbed about him. . . Tonight during the testimony meeting Inayat Masih arose and denied Christ before the people. As the altar service was in progress I felt strength in my bones and sent some of the best pray-ers, including Misri Lal and Shah, to surround him and pray the evil spirit out of him. What 